\title{
Hubungan antara Riwayat Kejang pada Keluarga dengan Tipe Kejang Demam dan Usia Saat Kejang Demam Pertama
}

\author{
Atut Vebriasa, Elisabeth S. Herini, Rina Triasih \\ Bagian Ilmu Kesehatan Anak Fakultas Kedokteran Universitas Gadjah Mada - RSUP. Dr. Sardjito, \\ Yogyakarta
}

\begin{abstract}
Latar belakang. Salah satu faktor risiko kejang demam adalah riwayat kejang pada keluarga, dihubungkan dengan tipe kejang demam pertama dan usia saat terjadi kejang demam pertama. Beberapa penelitian menunjukkan riwayat kejang meningkatkan risiko kejang demam kompleks sebagai tipe kejang demam pertama dan berhubungan dengan usia kejang demam pertama yang lebih dini.

Tujuan. Mengetahui hubungan riwayat kejang pada keluarga dengan tipe kejang demam pertama dan usia saat kejang demam pertama.

Metode. Penelitian dilaksanakan di Bagian Ilmu Kesehatan Anak RSUP Dr. Sardjito, Yogyakarta sejak Januari 2009-Juli 2010. Pengambilan sampel dilakukan secara konsekutif dan dikelompokkan berdasarkan ada tidaknya riwayat kejang pada keluarga, tipe kejang demam pertama, dan usia saat terjadi kejang demam pertama.

Hasil. Seratus lima puluh anak usia 6 bulan-5 tahun yang memenuhi kriteria inklusi dan eksklusi diikutsertakan dalam penelitian. Terdapat 91 (60,6\%) anak yang mempunyai riwayat kejang pada keluarga dan kejang demam pertama terjadi pada usia yang lebih dini pada kelompok ini (median usia 13,0 vs 17,0 bulan; IK95\%: 0,00-0,03; p=0,01). Anak dengan riwayat kejang lebih banyak mengalami kejang demam sederhana dibandingkan kejang demam kompleks (61,4\% vs 59,2\%), meskipun perbedaannya tidak bermakna (IK95\%: 0,78-1,37; p=0,80)

Kesimpulan. Anak dengan riwayat kejang pada keluarga cenderung mengalami kejang demam pertama pada usia yang lebih dini. Riwayat kejang pada keluarga tidak meningkatkan risiko terjadi kejang demam kompleks sebagai tipe kejang demam pertama. Sari Pediatri 2013;15(3):137-40.
\end{abstract}

Kata kunci: kejang demam, riwayat keluarga, usia saat kejang demam pertama

\footnotetext{
Alamat korespondensi:

Dr. Atut Vebriasa, Sp.A, Bagian Ilmu Kesehatan Anak Fakultas Kedokteran Universitas Gadjah Mada-RSUP. Dr. Sardjito, Jalan Kesehatan No. 1 Sekip Yogyakarta 55284, Indonesia. Telp. (0274) 561616, Fax. (0274) 583745, E-mail: dr_vebriasa@yahoo.com
}

Tejang demam (KD) adalah bangkitan kejang yang terjadi karena kenaikan suhu tubuh (suhu rektal di atas $38^{\circ} \mathrm{C}$ ) yang disebabkan oleh suatu proses ekstrakranium. ${ }^{1}$ Kejang demam merupakan penyebab tersering kejang pada 
anak. Insiden kejang demam di dunia bervariasi antara 2\%-5\% di Amerika Serikat, Amerika Selatan, dan Eropa Barat, 5\%-10\% di India, 8,3\%-9,9\% di Jepang, dan $14 \%$ di Guam. ${ }^{2,3}$ Perbedaan tersebut mungkin disebabkan oleh faktor kerentanan (suseptibilitas) secara genetik. ${ }^{4}$

Kejang demam cenderung terjadi dalam satu keluarga, walaupun pola pewarisan sampai sekarang belum jelas. ${ }^{5}$ Anak yang mengalami kejang demam cenderung mempunyai riwayat kejang demam pada keluarga. Anak yang mengalami kejang demam juga lebih sering dijumpai riwayat kejang tanpa demam pada keluarga, walaupun masih belum ada bukti yang jelas., 2,6

Hubungan antara riwayat kejang pada keluarga dengan tipe kejang demam pertama masih menjadi perdebatan. Penelitian oleh Wadhwa $\mathrm{dkk}^{7}$ menunjukkan bahwa anak yang mempunyai riwayat kejang pada keluarga lebih banyak yang mengalami kejang demam kompleks sebagai tipe kejang demam pertama dibandingkan anak yang tanpa riwayat kejang pada keluarga. Namun, hasil berbeda didapatkan oleh Stuijvenberg $\mathrm{dkk}^{8}$ yang melaporkan bahwa riwayat kejang pada keluarga tidak meningkatkan risiko terjadinya kejang demam kompleks sebagai tipe kejang demam pertama.

Riwayat kejang demam pada keluarga juga dihubungkan dengan onset kejang demam pada usia yang lebih dini. Penelitian sebelumnya menunjukkan bahwa rerata usia saat timbulnya kejang demam adalah 22,2 bulan, dan pada anak dengan riwayat kejang demam pada keluarga 14,5 bulan. ${ }^{9}$

\section{Metode}

Penelitian dilaksanakan di Bagian Ilmu Kesehatan Anak RSUP Dr. Sardjito, Yogyakarta sejak Januari 2009 - Juli 2010 dengan menggunakan desain penelitian potong lintang. Penelitian telah mendapat persetujuan dari Komite Etik Medik Fakultas Kedokteran Universitas Gadjah Mada/RSUP Dr. Sardjito, Yogyakarta. Pengambilan sampel dilakukan secara konsekutif. Semua anak yang memenuhi kriteria inklusi dan eksklusi dimasukkan sebagai subyek penelitian. Kriteria inklusi adalah anak usia 6 bulan -5 tahun yang mengalami kejang demam dan persetujuan orang tua dengan menandatangani informed consent. Sedangkan kriteria eksklusi adalah anak dengan infeksi susunan saraf pusat (meningitis, ensefalitis), gangguan keseimbangan elektrolit pada saat terjadinya kejang demam, adanya kelainan/defisit neurologis sebelum dan sesudah kejang demam, anak dengan gangguan perkembangan dan riwayat kejang tanpa demam sebelumnya.

Pengumpulan data dilakukan dengan cara melakukan wawancara pada orang tua pasien. Subyek penelitian dikelompokkan berdasarkan ada/tidaknya riwayat kejang pada keluarga, kemudian ditentukan tipe kejang demam pertama, kejang demam sederhana atau kejang demam kompleks. Usia saat terjadi kejang demam pertama juga dicatat.

Analisis statistik dilakukan untuk melihat hubungan riwayat kejang pada keluarga dengan tipe kejang demam pertama dan usia saat terjadi kejang demam pertama. Uji statistik yang digunakan yaitu uji chi square (hubungan antara riwayat kejang pada keluarga dengan tipe kejang demam pertama) dan uji Mann-Whitney $\mathrm{U}$ (hubungan antara riwayat kejang pada keluarga dengan usia timbulnya kejang demam pertama). Tingkat kemaknaan yang digunakan adalah $\alpha=0,05$.

\section{Hasil}

Selama kurun penelitian, 160 anak datang ke RSUP Dr. Sardjito dengan kejang demam, 156 anak di antaranya memenuhi kriteria inklusi, 4 anak lain menolak ikut penelitian. Enam anak dieksklusi karena kemudian didiagnosis sebagai meningitis/meningoensefalitis dan adanya abnormalitas neurologis. Karakteristik dasar subyek penelitian tertera pada Tabel 1 .

Anak dengan riwayat kejang pada keluarga lebih banyak yang mengalami kejang demam sederhana sebagai tipe kejang demam pertama dibandingkan kejang demam kompleks (61,4\% vs 59,2\%), meskipun perbedaannya tidak bermakna $(\mathrm{RP}=1,03$; IK95\%: 0,78-1,37; $\mathrm{p}=0,80$ ) (Tabel 2). Median usia terjadi kejang demam pertama pada anak yang mempunyai riwayat kejang pada keluarga lebih dini dibandingkan anak tanpa riwayat kejang pada keluarga, yaitu 13,0 $(11,0-18,0)$ bulan vs $17,0(11,0-29,0)$ bulan (IK95\%: 0,00-0.03; $\mathrm{p}=0,01)$ (Tabel 3).

\section{Pembahasan}

Kami mendapatkan anak dengan riwayat kejang pada keluarga lebih banyak yang mengalami kejang 
Tabel 1. Karakteristik dasar subyek penelitian

\begin{tabular}{ll}
\hline Variabel & $\mathrm{N}=150$ \\
\hline Usia, median (IQR) bulan & $17,0(13,0-29,25)$ \\
Jenis kelamin (\%) & $85(56,7)$ \\
$\quad$ Laki-laki & $65(43,3)$ \\
$\quad$ Perempuan & $101(67,3)$ \\
Tipe kejang demam pertama (\%) & $49(32,7)$ \\
$\quad$ Sederhana & \\
$\quad$ Kompleks & $83(55,4)$ \\
Riwayat keluarga (\%) & $4(2,6)$ \\
Kejang demam & $91(60,6)$ \\
Epilepsi & $59(39,4)$ \\
Kejang (kejang demam dan atau epilepsi) & $15,0(11,0-24,0)$ \\
$\quad$ Tanpa riwayat kejang & \\
Usia KD pertama, median (IQR) bulan &
\end{tabular}

$\mathrm{KD}=$ kejang demam, $\mathrm{IQR}=$ inter quartile range

Tabel 2. Hubungan riwayat kejang pada keluarga dengan tipe kejang demam pertama

\begin{tabular}{lccc}
\hline Tipe riwayat kejang pada keluarga & KDS & KDK & $\mathrm{p}$ \\
\hline Riwayat kejang demam & & & 0,88 \\
Ada & 59 & 28 & \\
$\quad$ Tidak & 42 & 21 & 0,48 \\
Riwayat epilepsi & & & \\
$\quad$ Ada & 6 & 2 & \\
$\quad$ Tidak & 95 & 47 & 0,80 \\
Riwayat kejang demam dan epilepsi & & & \\
Ada & 62 & 29 & \\
$\quad$ Tidak & 39 & 20 &
\end{tabular}

KDS = kejang demam sederhana, $\mathrm{KDK}$ = kejang demam kompleks

Tabel 3. Hubungan riwayat kejang pada keluarga dengan usia saat timbulnya kejang demam pertama

\begin{tabular}{lcc}
\hline Variabel & $\begin{array}{c}\text { Median usia timbulnya KD } \\
\text { pertama [median (IQR) bulan] }\end{array}$ & $\mathrm{p}$ \\
\hline Riwayat kejang pada keluarga & $13,0(11,0-18,0)$ & 0,013 \\
Ada & $17,0(11,0-29,0)$ & \\
Tidak & & \\
\hline
\end{tabular}

demam sederhana sebagai tipe kejang demam pertama dibandingkan kejang demam kompleks. Hasil tersebut berbeda dengan hasil penelitian Verity dkk, ${ }^{7}$ Wadhwa $\mathrm{dkk},{ }^{10}$ dan Birca dkk ${ }^{11}$ yang melaporkan bahwa anak yang mempunyai riwayat kejang pada keluarga lebih banyak yang mengalami kejang demam kompleks sebagai tipe kejang demam pertama dibandingkan anak yang tanpa riwayat kejang pada keluarga. Namun, hasil penelitian kami sesuai dengan penelitian Stuijvenberg dkk, ${ }^{8}$ Ling, ${ }^{9}$ dan Siddiqui ${ }^{12}$. Hasil yang bevariasi menunjukkan bahwa pengaruh genetik terhadap kejang demam sangat luas, terus berkembang, dan rumit mengingat kompleksitas dari penyakit kejang demam. ${ }^{13}$

Penelitian kami menunjukkan bahwa anak dengan riwayat kejang pada keluarga mempunyai onset kejang demam pertama pada usia yang lebih dini. Median usia terjadi kejang demam pertama pada anak yang mempunyai riwayat kejang pada keluarga adalah 13,0 $(11,0-18,0)$ bulan dan anak tanpa riwayat kejang pada 
keluarga adalah 17,0 (11,0-29,0) bulan. Hasil tersebut sesuai dengan penelitian sebelumnya yang melaporkan bahwa kejang demam pertama terjadi pada usia yang lebih muda pada anak yang mempunyai riwayat kejang pada keluarga. ${ }^{8,9,14}$

Kelemahan penelitian kami adalah dalam pengambilan data. Data riwayat kejang pada keluarga didapatkan hanya dari wawancara dengan orang tua saat pertama pasien masuk rumah sakit. Mungkin saja terjadi recall bias pada saat wawancara sehingga data yang didapat bukan data yang sebenarnya.

\section{Kesimpulan}

Anak dengan riwayat kejang pada keluarga cenderung mengalami kejang demam pertama pada usia yang lebih dini. Riwayat kejang pada keluarga tidak meningkatkan risiko timbulnya kejang demam kompleks sebagai tipe kejang demam pertama.

\section{Daftar pustaka}

1. Soetomenggolo TS. Kejang demam. Dalam: Soetomenggolo TS, Ismael S, penyunting. Buku ajar neurologi anak. Jakarta: Badan Penerbit IDAI; 1999. h. 244-52.

2. Hirtz DG. Febrile seizure. Ped in Rev 1997;18:5-9.

3. Varma RR. Febrile seizures. Indian J Pediatr 2002;69: 697-700.

4. Ali W, Bhat MA, Ahmad P, Iqbal J. Basics of convulsive disorders: febrile seizures. JK-Practitioner 2006;13:1613.

5. Kjeldsen MJ, Kyvik KO, Friis ML, Christensen K.
Genetic and environmental factors in febrile seizures: a Danish population-based twin study. Epilepsy Res 2002;51:167-77.

6. Greenberg AD, Holmes GL. The genetics of febrile seizure. Dalam: Baram TZ, Shinar S. penyunting. Febrile seizure. San Diego: Academic Press;2002.h.185-90.

7. Wadhwa N, Bharucha B, Chablani U, Contractor N. An epidemiological study of febrile seizures with special reference to family history and HLA linkage. Indian Pediatr 1992;29:1479-85.

8. Stuijvenberg van M, Beijeren van E, Wils NH, DerksenLubsen G, Duijn van CM, Moll HA. Characteristics of the initial seizure in familial febrile seizures. Arch Dis Child 1999;80:178-80.

9. Siddiqui TS. Febrile convulsions in children: relationship of family history to type of convulsions and age at presentation. J Ayub Med Coll Abbottabad 2001;14:268.

10. Verity CM, Butler NR, Golding J. Febrile convulsions in a national cohort followed up from birth, prevalence and recurrence in the first five years of life. Br Med J 1985;290:1307-10.

11. Birca A, Guy N, Fortier I, Cossette P, Lortie A, Carmant L. Genetic influence on the clinical characteristics and outcome of febrile seizures--a retrospective study. Eur J Paediatr Neurol 2005;9:339-45.

12. Ling SG. Clinical characteristics and risk factors for a complex first febrile convulsion. Singapore Med J 2001;42:264-7.

13. Waruiru C, Appleton R. Febrile seizures: an update. Arch Dis Child 2004;89:751-6.

14. Plochl E, Laubichler W. Retrospective study of 160 children with febrile convulsions. Klin Paediatr 1992;204:16-20. 